DOI: http://doi.org/10.21698/simi.2017.0038

\title{
STUDY OF BACTERIA RESISTANCE MECHANISMS IN RESPONSE TO A STRESS INDUCED BY PHARMACEUTICALS COMPOUNDS
}

\author{
Logan Marthe ${ }^{1 *}$, Catalina Stoica ${ }^{2 *}$, Laura Florentina Chiriac ${ }^{2}$, Toma Galaon ${ }^{2}$, Mihai Nita-Lazar $^{2}$ \\ ${ }^{1}$ Université de Perpignan Via Domitia, Institut Universitaire de Technologie, Department Genie \\ Biologique, Perpignan, France \\ ${ }^{2}$ National Research and Development Institute for Industrial Ecology-ECOIND Bucharest, \\ 71-73 Drumul Podu Dambovitei, 060652, Bucharest, Romania, mihai.nita@incdecoind.ro \\ *authors with equal contribution
}

\begin{abstract}
Three pharmaceutical compounds (Trimethoprim, Carbamazepine and Benzethonium chloride) were investigated to unveil possible toxic effects on two bacterial strains (Citrobacter freundii and Comamonas testosteroni). The pharmaceutical compounds stress triggered a bacterial defence mechanism which was evaluated at transcriptional and translational levels. In this study, potential bacterial biomarkers induced by the pharmaceutical stress were unraveled.
\end{abstract}

Keywords: biological adaptive markers, pharmaceutical compounds, gram-negative bacteria, defense mechanisms.

\section{Introduction}

Human welfare has been always based on their direct interest, so the economy was built on the expenses of the environment protection. The compounds resulting from anthropogenic activities, including the wastes generated through industrial and domestic activities could be very harmful to the environment, threatening the existence of entire populations and species.

In spite of this fact, all living organisms have developed particular adapting mechanisms to fight the effect of these contaminants / pollutants by spontaneous mutations (genetic variability) and activation of various defense mechanisms. Moreover, organisms react differently to pollutants according to their species, but their defense mechanisms could be very similar from prokaryotes to eukaryotes. Biological models, especially the bacterial ones, are very useful tools to observe the toxic effect of different pollutants by quantifying the EC50 based on the bacterial growth curve (Nita-Lazar et al. 2016). Bacteria react to various environmental condition (including pharmaceutical compounds-PhCs) by appointing different paths of regulation such as metabolic, translational and transcriptional regulation (van Hijum et al 2009).

Bacteria, as a biological model, was also selected due to ethical point of view, its biological simplicity as well as their handling. Bacteria grown in presence of toxic compounds could resist by different defense mechanisms, or die if the contaminant could reach vital biological pathways (Adams et al. 2015). In most cases, these microorganisms can develop a resistant strain via possible genetic mutations. Bacteria have several mechanisms of resistance such as horizontal gene transfer, elevated mutation rates, adaptive resistance, changes in cell permeability and efflux pumps 


\section{INTERNATIONAL SYMPOSIUM "THE ENVIRONMENT AND THE INDUSTRY", SIMI 2017, PROCEEDINGS BOOK}

(Schroeder et al. 2017). The efflux pump is a physical channel to expelling the toxin from inside the cell to outside it.

This study focused on two gram-negative bacteria, Citrobacter freundii, a long rodshaped bacterium and usually motile and Comamonas testosteroni an aerobic, motile, non-spore-forming, medium-to-long gram-negative bacillus (Banciu et al. 2016) chosen as a result of our previous ecotoxicological studies (Nita-Lazar et al. 2016). The complexity of this study was due to the interdisciplinary approach going from gene expression to protein.

In this context, the present paper aims to detect the possible mechanisms responsible of this resistance to pharmaceutical compound induced both at transcriptional level by the overexpression or inhibition of some genes linked to these defence mechanisms and translational level.

\section{Materials and Methods}

\section{Bacterial strains}

Citrobacter freundii (ATCC 8090) and Comamonas testosteroni (ATCC 11996) were purchased from ATCC.

\section{Reagents}

Growth medium was composed of tryptone soya agar (Oxoid, UK) and Lauryl Sulphate Broth (Himedia Laboratories Pvt. Ltd.). Pharmaceutical compounds Trimethoprim (TMP), Carbamazepine (CBZ) and Benzethonium chloride (BC) were purchased from Sigma-Aldrich (Sigma Corp. St. Louis, MO, USA) (Table 1).

Table 1. Description of the pharmaceutical compounds (according to Nita-Lazar et al. 2016)

\begin{tabular}{|c|c|c|c|c|}
\hline Name & $\begin{array}{c}\text { Formula/ } \\
\mathbf{M}^{*}(\mathrm{Da})\end{array}$ & $\begin{array}{c}\text { Structure/ } \\
\text { Chemical Classification }\end{array}$ & $\begin{array}{c}\mathrm{mp}^{* *}(\mathrm{C}) / \\
\rho^{* * *}(\mathrm{~g} / \mathrm{mL})\left(20^{\circ} \mathrm{C}\right)\end{array}$ & Water Solubility \\
\hline $\begin{array}{l}\text { Benzethonium } \\
\text { chloride }\end{array}$ & $\begin{array}{c}\mathrm{C}_{27} \mathrm{H}_{42} \mathrm{NO}_{2} \\
\mathrm{Cl} \\
448.1\end{array}$ & & $\begin{array}{c}162-164 \\
0.998\end{array}$ & $\begin{array}{c}1-5 \mathrm{~g} / 100 \mathrm{~mL} \text { at } \\
18^{\circ} \mathrm{C}\end{array}$ \\
\hline Carbamazepine & $\begin{array}{c}\mathrm{C}_{15} \mathrm{H}_{12} \mathrm{~N}_{2} \mathrm{O} \\
236.09\end{array}$ & Iminostilbene & $\begin{array}{c}189-192 \\
1.296\end{array}$ & insoluble in water \\
\hline Trimethoprim & $\begin{array}{c}\mathrm{C}_{14} \mathrm{H}_{18} \mathrm{~N}_{4} \mathrm{O} \\
3 \\
290.32\end{array}$ & Pyrimidine & $\begin{array}{c}238-240 \\
1.3\end{array}$ & slightly soluble \\
\hline
\end{tabular}




\section{INTERNATIONAL SYMPOSIUM "THE ENVIRONMENT AND THE INDUSTRY", SIMI 2017, PROCEEDINGS BOOK}

The PhCs and the concentrations (Table 2) were selected according to EC50 obtained by Nita-Lazar et al. (2016) so as to increase the chances to induce biomarkers of the resistance phenomenon.

Table 2. The chemicals concentration selected for the bacterial assay

\begin{tabular}{c|ccc}
\hline Bacterial strains & TMP & CBZ & BC \\
\hline C. freundii (\#3) & $80 \mathrm{mg} / \mathrm{L}$ & $80 \mathrm{mg} / \mathrm{L}$ & $3 \mathrm{mg} / \mathrm{L}$ \\
C. testosteroni $(\# 4)$ & $7,5 \mathrm{mg} / \mathrm{L}$ & $80 \mathrm{mg} / \mathrm{L}$ & $3,5 \mathrm{mg} / \mathrm{L}$ \\
\hline
\end{tabular}

\section{Bacterial assay}

Each bacterial strain was grown on tryptone soya agar and it was incubated over night $(\mathrm{O} / \mathrm{N})$ at $37^{\circ} \mathrm{C}$. A single colony from each bacterial strain was then incubated $\mathrm{O} / \mathrm{N}$ in $10 \mathrm{ml}$ Lauryl Sulphate Broth at $37^{\circ} \mathrm{C}$ at $130 \mathrm{rpm}$ (New Brunswick Scientific, Innova 44). Optical density (OD) was measured at $600 \mathrm{~nm}$ using UV-VIS Spectrometer (VWR International, USA). The OD $600 \mathrm{~nm}$ was measured and a bacterial density of 0.3 OD $600 \mathrm{~nm}$ was incubated for $4 \mathrm{~h}$ in absence (control) or presence of TMP, CBZ and BC.

mRNA assay

RNA extraction was preformed according the protocol described into the PureLink RNA Mini kit (Invitrogen, Life Technologies, USA). RNA extracted concentration was detected by nanodrop (ClarioStar microplate reader, BMG Labtech, Germany) and it was used to quantify the purity and concentration of each extracted sample. The absorbance was measured at two different wavelengths: $260 \mathrm{~nm}$, to measure the concentration of the RNA (its absorbance wavelength) and at $280 \mathrm{~nm}$, to measure its purity (the absorbance wavelength of proteins). Four set of primers

NIRk1f/NIRk5 (specific to denitrifying bacteria, 514bp mRNA strand); iii) NOSzf/NOSz1622r (specific to denitrifying bacteria, 453bp mRNA strand); iv) pao462f/pao651r (specific to phosphate accumulating bacteria, 429bp strand) (Braker et al 1998) were used to amplify the mRNA by SuperScript ${ }^{\mathrm{TM}}$ III One-Step RT-PCR System with Platinum ${ }^{\mathrm{TM}}$ Taq DNA Polymerase protocol. The RT-PCR kit has a Reverse transcriptase enzyme which synthetize cDNA strands from each mRNA strands: this reaction constitutes the first step. Then, by heating at a specific temperature, the cDNA could be amplified by a classic PCR reaction where the primers are attached and amplified on their specifics sites by the Taq DNA polymerase enzyme. The addition of the nucleotides on the single DNA strand from the sense primer to the reverse primer formed a new double strand DNA used as a template in a new cycle.

A program of 40 cycles was divided in three steps: i) denaturing DNA at $95^{\circ} \mathrm{C}$; ii) annealing at $55^{\circ} \mathrm{C}$ and iii) amplifying at $68^{\circ} \mathrm{C}$ and it was set at PCR system (Applied Biosystems).

The PCR products were separated by electrophoresis on a $1 \%$ agarose gel mixed with the ethidium bromide tagging substance. The ethidium bromide tagged in a blue color each strand between its base pairs for identification. The smallest strands migrated further than the biggest ones; in order to know their length a reference to $1 \mathrm{kbp}$ and $100 \mathrm{bp}$ ladders was done. 


\section{INTERNATIONAL SYMPOSIUM "THE ENVIRONMENT AND THE INDUSTRY", SIMI 2017, PROCEEDINGS BOOK}

\section{Protein assays}

Bacteria were lysed in the extraction buffer containing phenylmethylsulphonyl fluoride (PMSF) by sonication. After sonication and vortexing the samples, the protein concentration was measured at $280 \mathrm{~nm}$.

The electrophoresis on acrylamide gel was done to separate the proteins depending on their size by referring to a ladder. The gel was stained with Coomassie blue and the bands made by different proteins were observed. The staining process consisted in four steps: 1) the gel was fixed with a $40 \%$ ethanol $10 \%$ acetic acid solution for 15 minutes, 2) the gel was rinsed with distilled water, 3) the gel was placed into Coomassie blue for 24 hours to have a better recovery of the bands and 4) the gel was rinsed again 3 times with tap water. The blue colored bands (corresponding of the proteins) and their size by comparing with the ladder were observed.

\section{Results and Discussion}

\section{Bacterial assay}

An antibiotic for bladder infections (TMP), an antiepileptic drug (CBZ) and an antimicrobial agent (BC) (American Society of Health 2015) were used as a stress factors for gram-negative bacteria. Bacterial was grown in presence of $\mathrm{PhCs}$ for 4-5 at $37^{\circ} \mathrm{C}$ (Table 2 ) then pelleted for mRNA and protein extractions.

\section{mRNA extraction}

The results of mRNA extraction showed a robust extraction with the exception of bacteria \#3 grown in presence of BC (Table 3). This could be explained by the limited growth in presence of this particular PhCs.

Table 3. mRNA concentrations and mass in the RT PCR mix

\begin{tabular}{c|c|cccc}
\hline \multicolumn{2}{c}{ Samples } & $\begin{array}{c}\text { RNA } \\
\text { concentration } \\
\text { (ng/ } \boldsymbol{\mu L})\end{array}$ & $\begin{array}{c}\text { Dilution } \\
\text { factor }\end{array}$ & $\begin{array}{c}\text { RNA } \\
\text { template } \\
\text { concentration } \\
(\mathbf{n g})\end{array}$ & $\begin{array}{c}\text { Water } \\
\text { volume } \\
(\boldsymbol{\mu L} \mathbf{L})\end{array}$ \\
\hline \multirow{3}{*}{$\# 3$} & Ctrl & 2622,77 & 5 & 524,4 & 14 \\
& TMP & 2490,79 & 5 & 498,2 & 14 \\
& CBZ & 1442,54 & 3 & 480,9 & 14 \\
& BC & 41,02 & - & 410,2 & 5 \\
\hline \multirow{3}{*}{$\# 4$} & Ctrl & 251,96 & - & 503,9 & 13 \\
& TMP & 180,78 & - & 542,4 & 12 \\
& CBZ & 372,87 & 2 & 559,3 & 12 \\
& BC & 171,38 & - & 514,1 & 12
\end{tabular}

\#3 - C. freundii strain; \#4 - C. testosteroni strain; Ctrl-control; TMP - Trimethoprim; CBZ Carbamazepine; $\mathrm{BC}$ - Benzenthonium chloride.

The protein concentrations $(\mathrm{mg} / \mathrm{mL})$ was obtained by reading at $280 \mathrm{~nm}$ absorbance (Table 4).

After RT-PCR an electrophoresis on a $1 \%$ agarose gel mixed with the ethidium bromide tagging substance was proceed. Several differences between the samples were revealed (Figure 1). No particular bands were observed for C. freundii strain, 


\section{INTERNATIONAL SYMPOSIUM "THE ENVIRONMENT AND THE INDUSTRY", SIMI 2017, PROCEEDINGS BOOK}

but a very intense band of $1300 \mathrm{bp}$ molecular weight was detected in case of $C$. testosteroni $(\mathrm{Ctrl})$ and $C$. testosteroni stressed with $\mathrm{BC}$.

Table 4. Bacteria proteins concentration

\begin{tabular}{c|c|c}
\hline \multicolumn{2}{c|}{ Samples } & $\begin{array}{c}\text { Proteins concentration } \\
(\mathbf{m g} / \mathbf{m l})\end{array}$ \\
\hline \multirow{3}{*}{$\# 3$} & Ctrl & 4,42232 \\
& TMP & 4,3778 \\
& CBZ & 4,457512 \\
$\# 4$ & BC & 4,094992 \\
\hline \multirow{3}{*}{$\# 4$ Ctrl } & 4,142904 \\
& TMP & 4,347272 \\
& CBZ & 4,340912 \\
& BC & 4,111952 \\
\hline
\end{tabular}

\#3 - C. freundii strain; \#4 - C. testosteroni strain; Ctrl-control; TMP - Trimethoprim; CBZ Carbamazepine; $\mathrm{BC}$ - Benzenthonium chloride.

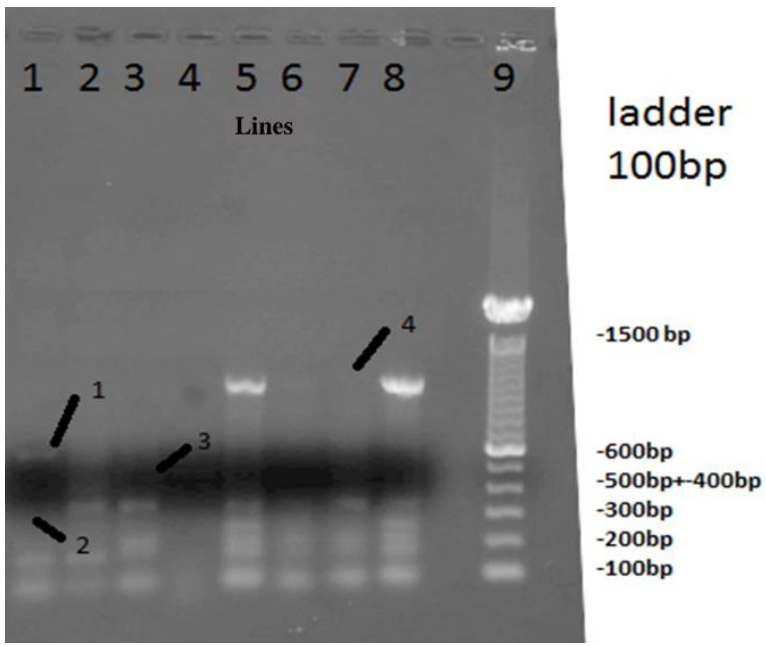

Figure 1. RT-PCR Gene Extract (mRNA) from $C$. freundii, lines: 1 (control), 2 (TMP), 3 (CBZ), 4 (BC) and C. testosteroni, lines: 5 (control), 6 (TMP), 7 (CBZ), 8 (BC). Amplification of the universal bacterial gene (U), around $1500 \mathrm{bp} P C R$ product; amplification of gene involved in nitrite reduction $\left(\mathrm{NO}_{2}\right)$ processes, around $520 \mathrm{bp}$ PCR product; amplification of gene involved in nitrogen oxide $\left(\mathrm{N}_{2} \mathrm{O}\right)$ reduction processes, around $450 \mathrm{bp} P C R$ product; amplification of the gene involved in phosphorylation $(P)$ processes around 300 bp PCR product. Potential biomarkers, bands $1,2,3,4$.

The results showed that the band 1 biomarker present in $C$. freundii (line 1) was not found as intensity and presence in $C$. freundii incubated in the presence of the three $\mathrm{PhCs}$ (line 2-3-4), which implies a specific inhibition of metabolic pathways in which 


\section{INTERNATIONAL SYMPOSIUM "THE ENVIRONMENT AND THE INDUSTRY", SIMI 2017, PROCEEDINGS BOOK}

this gene was functional. Band 2 biomarker was missing from the control (line 1), but was induced by the toxic activity of TMP and CBZ, but not of BC. The band 3 biomarker was induced only by CBZ compared to the control (line 1). The band 4 biomarker was completely inhibited by the CBZ, and it was induced at a same level with the control (line 5) by BC (line 8 ).

\section{Protein extraction}

The SDS-PAGE electrophoresis showed very smaller bands than the two other samples \#3 TMP and \#3CBZ (Figure 2).

It was also detected that \#3 TMP and \#3CBZ had a really thick band between 50 and $75 \mathrm{kD}$, according to the Dual Color Prestained Protein Standard scale (BioRad, USA), which means that $C$. freundii strain stressed with TMP and CBZ expressed much more the proteins than \#3 $\mathrm{BC}$.

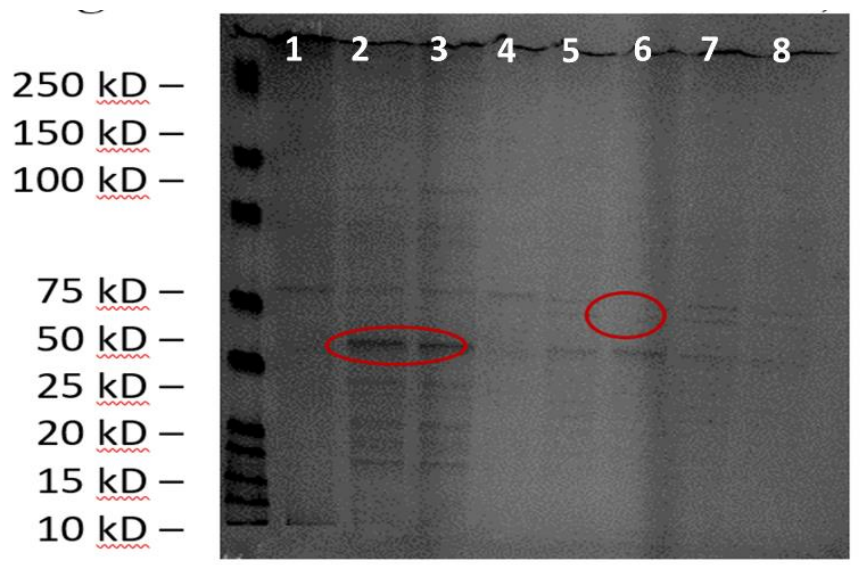

Figure 2. Bacteria proteins gel from $C$. freundii, lines: 1 (control), 2 (TMP), 3 (CBZ), 4 (BC) and C. testosteroni, lines: 5 (control), 6 (TMP), 7 (CBZ), 8 (BC).

This may be due to their resistance mechanisms involved especially since bacteria usually combine many proteins to metabolize or to expel the contaminant outside the cell (efflux pump). The thickest band it was observed for \#3 TMP and \#3 CBZ samples around $50 \mathrm{kD}$ corresponds to a big amount of the same protein due to an overexpressed gene. The same band was observed in the \#4 TMP lane, which is also thicker than the other samples such as \#4 Ctrl, \#4 CBZ and \#4 BC which were not inhibited by the chemicals. This protein might be a biomarker of the resistance mechanism. The presence of the bands in these samples lanes than in the \#3 ctrl one was correlated with the mRNA profile, so that more genes and proteins were expressed. The results of protein extraction were very good corroborated with the mRNA ones (Figure 1), since three bands (marked in red) corresponding with the 2, 3 and 6 lines appeared as an overexpression of proteins due to toxic activity induced by TMP and CBZ in case of $C$. freundii strain as well as TMP, respectively in case of C. testosteroni. 


\section{INTERNATIONAL SYMPOSIUM "THE ENVIRONMENT AND THE INDUSTRY", \\ SIMI 2017, PROCEEDINGS BOOK}

\section{Conclusions}

The aim of this study was to determine the biomarkers of a biological resistance mechanism in response to chemical stress. One biological model (bacteria) was subjected to certain concentrations of chemicals in their growth medium. Toxicity tests were made to ascertain some differences between the bacteria strains in presence or absence of the PhCs. In terms of the bacteria mRNA and proteins, several marking differences on the protein bands between the stressed and unstressed strains which corresponds to the mRNA profile were observed. It can be considered a very interesting result because a trace of the bacterial resistance mechanisms through these proteins was revealed. Moreover, some biomarkers were identified such as the ones induced by TMP pressure on both $C$. freundii and $C$. testosteroni strains and CBZ pressure on $C$. freundii.

Future studies will be required to identify the proteins involved in these resistance mechanisms in order to know precisely which proteins were involved and in which resistance process, thus the mechanisms at a molecular level would be disclosed.

\section{Acknowledgements}

The present research was financially suported by the Romanian Core Program PN 16-25 0103.

\section{References}

Adams, GO, Fufeyin, PT, Okoro, SE, Ehinomen, I 2015, ‘Bioremediation, Biostimulation and Bioaugmention: A Review', International Journal of Environmental Bioremediation \& Biodegradation, vol. 3, no. 1, pp. 28-39.

Banciu, A, Niculescu, D, Nita-Lazar, M, Lucaciu, I, Stoica, C, Mihaescu, G 2016, 'Potentially pathogenic and antibiotic resistant bacteria in the Danube Delta aquatic ecosystem ', Journal of Environmental Protection and Ecology, vol. 17, no. 1, pp.127-135.

Braker, G, Fesefeldt, A, Witzel, KP 1998, `Development of PCR Primer Systems for Amplification of Nitrite Reductase Genes (nirK and nirS) To Detect Denitrifying Bacteria in Environmental Samples `, Applied and Environmental Microbiology, vol. 64, no. 10, pp. 3769-3775.

DNA extraction: PureLink Genomic DNA kits, Life technologies.

Nita-Lazar, M, Galaon, T, Banciu, A, Paun, I, Stoica, C, Lucaciu, I 2016, 'Screening of various harmful compounds in a new bacterial biological model', Journal of Environmental Protection and Ecology, vol.17, no. 1, pp. 237-247.

Nita-Lazar, M, Gheorghe, S, Anghelache, A, Banciu, A, Stoica, C, Lucaciu, I 2016, 'Modulation of the bacterial defense mechanisms by various chemical structures', Revista de Chimie, vol. 67, no. 8, pp.1454-1457.

Nothaft, H, \& Szymanski, CM 2010, 'Protein glycosilation in bacteria: sweeter than ever`, Nature Reviews Microbiology, vol. 8, pp. 765-778.

RNA extraction: PureLink RNA Mini Kit, Life technologies.

Schroeder, M, Brooks, BD, Brooks, AE, Wing, HJ 2017, ‘The Complex Relationship between Virulence and Antibiotic Resistance`, Genes, vol. 8, no. 1, pp. 39.

The American Society of Health-System Pharmacists, Retrieved Aug 1, 2015. van Hijum, SAFT, Medema, MH, Kuipers, OP 2009, `Mechanisms and Evolution of Control Logic in Prokaryotic Transcriptional Regulation', Microbiology and Molecular Biology Reviews, vol. 73, no.3, pp. 481-509. 